\title{
Cytotoxic rearranged angucycline glycosides from deep sea-derived Streptomyces lusitanus SCSIO LR32
}

\author{
Xiangcheng Zhu' ${ }^{1}$, Yanwen Duan ${ }^{1}$, Zhaomeng $\mathrm{Cui}^{2}$, Zhen $\mathrm{Wang}^{2}$, Zengxia $\mathrm{Li}^{2}$, Yun Zhang ${ }^{3}$, Jianhua $\mathrm{Ju}^{3}$ \\ and Hongbo Huang ${ }^{3}$
}

Two new rearranged linear angucycline glycosides, designated grincamycins $G$ and $H(1$ and 2 ), together with three known congers P-1894B (vineomycin $A_{1}, 3$ ), saquayamycin $B(4)$ and vineomycin $B_{2}(5)$, were obtained from marine-derived actinomycete Streptomyces lusitanus SCSIO LR32. The structures of 1 and 2 were elucidated by MS, 1D and 2D NMR techniques. Compounds $2-5$ showed significant inhibitory effect on Jurkat T-cell proliferation with $\mathrm{IC}_{50}$ values of $3.0,0.011$, 0.037 and $0.3 \mu \mathrm{M}$, respectively.

The Journal of Antibiotics (2017) 70, 819-822; doi:10.1038/ja.2017.17; published online 22 February 2017

\section{INTRODUCTION}

Angucycline is a large group of secondary metabolites originating from the fermentation extract of different actinomycetes, mostly from the species of Streptomyces. ${ }^{1}$ Angucycline compounds possess various biological and pharmacological properties, including cytotoxicity and antitumor, antibacterial and antiviral activities, as well as enzymeinhibition activities. ${ }^{1,2}$ Structurally, classic angucyclines contain an angular benz[a]anthracene scaffold and non-classic congers with rearranged linear tetracyclic or tricyclic core units, and most of angucyclines exist as glycosides in nature. The observed carbohydrates in angucycline glycoside usually are deoxy sugars, such as D-olivose, L- or D-rhodinose, L-aculose, L-cinerulose A, L-cinerulose B, D-kerriose and L-amicetose. ${ }^{1-3}$ Moreover, the typical $O$-glycoside and $C$-glycoside with different types of sugars or different numbers of sugar chains have brought broad chemical diversities to natural angucycline compounds.

During our efforts to screen for novel antitumor and antimicrobial antibiotics, we reported non-classic angucycline glycosides designated as grincamycins (GCNs) B-E from deep sea-derived actinomycete Streptomyces lusitanus SCSIO LR32. ${ }^{4}$ Subsequently, the biosynthetic gene cluster of GCN cloned from S. lusitanus SCSIO LR32 was heterologously expressed in Streptomyces coelicolor M512, resulting in the isolation of $\mathrm{P}-1894 \mathrm{~B}$ as a predominant product. ${ }^{5}$ The structural difference between P-1894B and GCN is that the terminal sugars L-cinerulose A in GCN were replaced by L-aculose units in P-1894B. In addition, the LC-MS analyses of metabolite derived from the strain SCSIO LR32 cultivated in a modified $\mathrm{AM}_{2}$ medium have detected two peaks with the molecular weight of 934.4, which were 4 units fewer than that of grincamycin and grincamycin B (molecular weight 938.4), which presumably could be $\mathrm{P}-1894 \mathrm{~B}$ and vineomycin $\mathrm{B}_{2}$. Based on these preliminary data, strain SCSIO LR32 was further fermented on an 801 scale. Subsequent purification of culture extract resulted in identification of five angucycline glycosides (1-5) containing L-aculose as terminal on the sugar chain (Figure 1). Hererin we report the fermentation, isolation, structure elucidation and cytotoxic activities of these compounds.

\section{RESULTS}

Structure elucidation

Compound 1 was isolated as a yellowish powder. (-)HR-ESI-MS of 1 revealed a quasimolecular ion peak at 801.2776, in combination with ${ }^{1} \mathrm{H}$ and ${ }^{13} \mathrm{C}$ NMR data, establishing the molecular formula as $\mathrm{C}_{43} \mathrm{H}_{46} \mathrm{O}_{15}$. The UV spectrum of 1 showed characteristic absorption bands at 214, 243, 265 and $443 \mathrm{~nm}$. The ${ }^{13} \mathrm{C}$ NMR spectrum disclosed five carbonyls at $\delta_{\mathrm{C}} 209.5,198.2,197.0,189.9$ and 189.8, 14 aromatic carbons in the downfield $\mathrm{sp}^{2}$ region and 24 aliphatic carbons in the upfield area (Table 1). The ${ }^{1} \mathrm{H}$ NMR spectroscopic signals at $\delta_{\mathrm{H}} 13.10(2 \mathrm{H}$, br s, 1-OH and 5-OH) suggested two hydrogen-bonded hydroxy groups. A pair of ortho-coupled aromatic protons at $\delta_{\mathrm{H}} 8.02(\mathrm{~d}, 8.0 \mathrm{~Hz}, \mathrm{H}-8)$ and $7.90(\mathrm{~d}, 8.0 \mathrm{~Hz}, \mathrm{H}-7)$ and a single aromatic proton at $\delta_{\mathrm{H}} 8.34(\mathrm{~s}, \mathrm{H}-12)$ were observed, which were almost consistent with those in grincamycin $\mathrm{E}^{4}$; inferred $\mathbf{1}$ had a linear tetracyclic anthraquinone aglycone. The $\mathrm{HMBC}$ correlations of H-7/C-6, C-9, C-10a, H-8/C-9, C-10, C-6a, H-12/C-1, C-4a, C-5a, $\mathrm{C}-11$ and of $\mathrm{H}-2 / \mathrm{C}-1, \mathrm{C}-4$ confirmed the existence of the linear tetracyclic anthraquinone unit (Figure 2). The Me-13 was attached at

\footnotetext{
${ }^{1}$ Xiangya International Academy of Translational Medicine, Central South University, National Engineering Research Center of Combinatorial Biosynthesis for Drug Discovery, Changsha, China; ${ }^{2}$ Key Laboratory of Metabolism and Molecular Medicine, the Ministry of Education, Department of Biochemistry and Molecular Biology, School of Basic Medical Sciences, Fudan University, Shanghai, China and ${ }^{3}$ CAS Key Laboratory of Tropical Marine Bio-resources and Ecology, Guangdong Key Laboratory of Marine Materia Medica, South China Sea Institute of Oceanology, Chinese Academy of Sciences, Guangzhou, China

Correspondence: Dr H Huang, CAS Key Laboratory of Tropical Marine Bio-resources and Ecology, Guangdong Key Laboratory of Marine Materia Medica, South China Sea Institute of Oceanology, Chinese Academy of Sciences, 164 West Xingang Road, Guangzhou 510301, China.

E-mail: huanghb@scsio.ac.cn

Received 18 August 2016; revised 21 December 2016; accepted 18 January 2017; published online 22 February 2017
} 
<smiles>[R]Cc1ccc2c(c1O)C(=O)c1cc3c(c(O)c1C2=O)C[C@@](C)(O[R2])CC3=O</smiles>

grincamycin $G(1)$

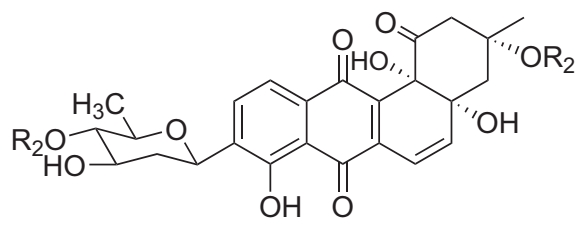

P-1894B (vineomycin $A_{1}, 3$ )<smiles>[R20]OC(C)C(C)OC(CC(O)c1ccc2c(c1O)C(=O)c1ccc(CC([R20])(C)CC(=O)O)c(O)c1C2=O)C(C)O</smiles>

vineomycin $B_{2} \quad(5)$

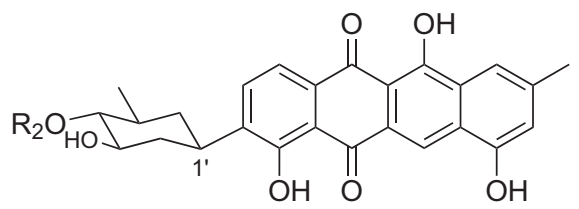

grincamycin $\mathrm{H}$ (2)<smiles>[R20]O[C@]1(C)CC(=O)[C@@]2(O)C3=C(C=C[C@@]2(O)C1)C(=O)c1c(ccc([R])c1O)C3=O</smiles>

saquayamycin B (4)

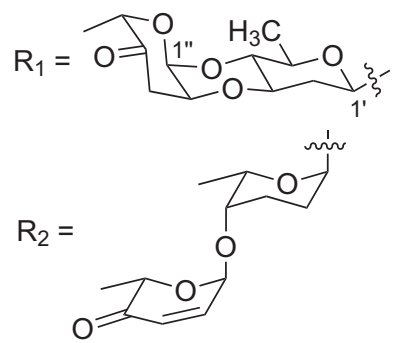

Figure 1 Chemical structures of compounds 1-5 from Streptomyces lusitanus SCSIO LR32.

C-3 based on the HMBC correlations of $\mathrm{H}_{3}-13 / \mathrm{C}-2, \mathrm{C}-3, \mathrm{C}-4$. Additionally, four doublet methyl signals at $\delta_{\mathrm{H}} 1.34, \delta_{\mathrm{C}} 18.4$ $\left(\mathrm{CH}_{3}-6^{\prime}\right), \delta_{\mathrm{H}} 1.28, \delta_{\mathrm{C}} 17.4\left(\mathrm{CH}_{3}-6^{\prime \prime}\right), \delta_{\mathrm{H}} 0.64, \delta_{\mathrm{C}} 18.4\left(\mathrm{CH}_{3}-6^{\prime \prime \prime}\right)$ and $\delta_{\mathrm{H}} 1.21, \delta_{\mathrm{C}} 16.4\left(\mathrm{CH}_{3}-6^{\prime \prime \prime \prime}\right)$, as well as four anomeric methine signals at $\delta_{\mathrm{H}} 5.07(\mathrm{~d}, 9.5), \delta_{\mathrm{C}} 73.3\left(\mathrm{CH}-1^{\prime}\right), \delta_{\mathrm{H}} 5.26(\mathrm{~d}, 3.0), \delta_{\mathrm{C}} 93.2$ $\left(\mathrm{CH}-1^{\prime \prime}\right), \delta_{\mathrm{H}} 5.17(\mathrm{br} \mathrm{s}), \delta_{\mathrm{C}} 91.9\left(\mathrm{CH}-1^{\prime \prime \prime}\right)$ and $\delta_{\mathrm{H}} 5.13(\mathrm{~d}, 3.4), \delta_{\mathrm{C}} 96.9$ $\left(\mathrm{CH}-1^{\prime \prime \prime \prime}\right)$, indicated the presence of four deoxysugars in 1 . Detailed comparison showed that the ${ }^{1} \mathrm{H}$ and ${ }^{13} \mathrm{C}$ NMR spectroscopic data of the sugar units were similar to those of grincamycin $\mathrm{D},{ }^{4}$ except that the signals of two methines in cinerulose A disappeared, while a set of signals ascribed to a double bond at $\delta_{\mathrm{H}} 6.93(10.3,3.4 \mathrm{~Hz})$, $\delta_{\mathrm{C}} 146.0\left(\mathrm{CH}-2^{\prime \prime \prime \prime}\right), \delta_{\mathrm{H}} 5.97(10.0 \mathrm{~Hz})$ and $\delta_{\mathrm{C}} 128.1\left(\mathrm{CH}-3^{\prime \prime \prime \prime}\right)$ was observed. Moreover, the ${ }^{13} \mathrm{C}$ NMR resonance of the carbonyl in cinerulose A was shifted upfield from $\delta_{\mathrm{C}} 210.9$ in grincamycin D to $\delta_{\mathrm{C}} 198.2$ in $\mathbf{1}$, indicating that the cinerulose $\mathrm{A}$ unit in grincamycin $\mathrm{D}$ was replaced by an aculose in 1 . The HMBC correlations of $\mathrm{H}-1^{\prime \prime \prime} / \mathrm{C}-4^{\prime \prime \prime \prime}$ confirmed the existence of an aculose- $(1 \rightarrow 4)$-rhodinosyl unit. The relative configurations of the anomeric carbons were defined as $\beta$ for olivose and $\alpha$ for cinerulose $\mathrm{B}$, rhodinose and aculose on the basis of the large coupling constant $(J=9.5 \mathrm{~Hz})$ of $\mathrm{H}-1^{\prime}$ and the small coupling constants of $\mathrm{H}-1^{\prime \prime}, \mathrm{H}-1^{\prime \prime \prime}$ and $\mathrm{H}-1^{\prime \prime \prime \prime}$, respectively. Being similar to the conversion of grincamycin into grincamycin $\mathrm{E}$ under UV irradiation, ${ }^{4}$ saquayamycin B (4) could be transformed to 1 in the same manner (Supplemantary Figure S15). Therefore, the absolute configuration of C-3 was established to be $R$, and the sugars were elucidated as $\beta$-D-olivose, $\alpha$-L-cinerulose $\mathrm{B}, \alpha$-L-rhodinose and $\alpha$-Laculose, which were identical with those of saquayamycin B (4). ${ }^{6}$ Compound 1 was named grincamycin G.

Compound 2 was isolated as a dark-red powder. Its molecular formula was determined to be $\mathrm{C}_{37} \mathrm{H}_{38} \mathrm{O}_{12}$ by analyses of (- )HR-ESIMS, as well as ${ }^{1} \mathrm{H}$ and ${ }^{13} \mathrm{C}$ NMR spectra, indicating 19 degrees of unsaturation. Detailed analyses of the ${ }^{1} \mathrm{H}$ and ${ }^{13} \mathrm{C}$ NMR spectroscopic data showed that the structure of $\mathbf{2}$ was similar to those of quanolirones and galtamycinone, ${ }^{7-9}$ which contained 1,5,10-trihydroxy-naphthacenequinone scaffold. The HMBC spectrum of $\mathbf{2}$ confirmed the position of a pair of ortho-coupled protons at $\delta_{\mathrm{H}} 7.79$ $(\mathrm{d}, 7.9 \mathrm{~Hz}, \mathrm{H}-7)$ and $7.85(\mathrm{~d}, 7.9 \mathrm{~Hz}, \mathrm{H}-8)$ and three singlet protons at $\delta_{\mathrm{H}} 6.97(\mathrm{H}-2), 7.55(\mathrm{H}-4)$ and $8.45(\mathrm{H}-12)$ (Figure 2). A methyl group $\left(\delta_{\mathrm{H}} 2.43, \delta_{\mathrm{C}} 21.8, \mathrm{Me}-13\right)$ was attached at C-3 based on the HMBC correlations from the methyl protons to C-2 $\left(\delta_{\mathrm{C}} 116.1\right), \mathrm{C}-3\left(\delta_{\mathrm{C}} 141.6\right)$ and $\mathrm{C}-4\left(\delta_{\mathrm{C}} 114.2\right)$. The ${ }^{1} \mathrm{H}$ and ${ }^{13} \mathrm{C}$ NMR spectroscopic data also revealed three anomeric carbon signals at $\delta_{\mathrm{H}} 4.80(\mathrm{~d}, 11.9)$ and $\delta_{\mathrm{C}} 70.5$ $\left(\mathrm{CH}-1^{\prime}\right), \delta_{\mathrm{H}} 4.94(\mathrm{br} \mathrm{s})$ and $\delta_{\mathrm{C}} 97.3\left(\mathrm{CH}-1^{\prime \prime}\right), \delta_{\mathrm{H}} 5.35(\mathrm{~d}, 3.1)$ and $\delta_{\mathrm{C}} 94.3\left(\mathrm{CH}-1^{\prime \prime \prime}\right)$, three methyl groups at $\delta_{\mathrm{H}} 1.30$ and $\delta_{\mathrm{C}} 18.3\left(\mathrm{Me}-6^{\prime}\right)$, $\delta_{\mathrm{H}} 1.10$ and $\delta_{\mathrm{C}} 16.7\left(\mathrm{Me}-6^{\prime \prime}\right), \delta_{\mathrm{H}} 1.24$ and $\delta_{\mathrm{C}} 14.9\left(\mathrm{Me}-6^{\prime \prime \prime}\right)$, as well as $(Z)-\alpha, \beta$-unsaturated carbonyl at $\delta_{\mathrm{H}} 7.08(10.2,3.1 \mathrm{~Hz})$ and $\delta_{\mathrm{C}} 144.7$ $\left(=\mathrm{CH}-2^{\prime \prime \prime}\right), \delta_{\mathrm{H}} 6.08(10.2 \mathrm{~Hz})$ and $\delta_{\mathrm{C}} 126.1\left(=\mathrm{CH}-3^{\prime \prime \prime}\right)$ and $\delta_{\mathrm{C}} 196.6$ $\left(\mathrm{C}-4^{\prime \prime \prime}\right)$, indicating the presence of a trisaccharide comprising three deoxysugars. Detailed analyses of the HMBC associations (Figure 2) revealed an $\alpha$-aculose-( $1 \rightarrow 4)$ - $\alpha$-rhodinosyl- $(1 \rightarrow 4)$ - $\beta$-olivosyl linked at C-9 of the naphthacenequinone to form a $C$-glycoside (Figure 2). ${ }^{10}$ The absolute configurations of the three deoxysugars were presumed to be identical with those in vineomycin $\mathrm{B}_{2}$ (5), which were $\alpha$-L-aculose, $\alpha$-L-rhodinose and $\beta$-D-olivose based on the ${ }^{13} \mathrm{C}$ NMR data for the trisaccharide in 2 being almost consistent with those in vineomycin $B_{2}$ (5) (Supplementary Table S1), as well as that 2 and $\mathbf{5}$ shared a biosynthesis pathway. Compound 2 was designated grincamycin $\mathrm{H}$.

The known compounds, $\mathrm{P}-1894 \mathrm{~B}$ (vineomycin $\mathrm{A}_{1}, 3$ ), ${ }^{11,12}$ saquayamycin $\mathrm{B}(\mathbf{4})^{6,13}$ and vineomycin $\mathrm{B}_{2}(5)^{10,14}$ were identified on the basis of comparisons of MS, ${ }^{1} \mathrm{H}$ and ${ }^{13} \mathrm{C}$ NMR spectroscopic data with the compounds previously reported.

\section{Cytotoxic activities}

In the in vitro cytotoxic assay, the known compounds P-1894B (vineomycin A1, 3) and saquayamycin B (4) exhibited significant 
Table $1{ }^{1} \mathrm{H}(500 \mathrm{MHz})$ and ${ }^{13} \mathrm{C}(125 \mathrm{MHz})$ NMR data of grincamycins $\mathrm{G}(1)$ and $H(2)$

\begin{tabular}{|c|c|c|c|c|}
\hline \multirow[b]{2}{*}{ Position } & \multicolumn{2}{|c|}{ Grincamycin G $(\mathbf{1})^{a}$} & \multicolumn{2}{|c|}{ Grincamycin $H(2)^{b}$} \\
\hline & $\delta_{C}$ type & $\delta_{H}$ mult. $(\mathrm{J}$ in $\mathrm{Hz})$ & $\delta_{C}$ type & $\delta_{H}$ mult. $(\mathrm{J}$ in $\mathrm{Hz})$ \\
\hline 1 & 197.0, C & & $155.9, \mathrm{C}$ & \\
\hline 2 & $52.5, \mathrm{CH}_{2}$ & $\begin{array}{c}2.56, \text { dd }(17.3,1.6) \\
2.90, \text { overlapped }\end{array}$ & $116.1, \mathrm{CH}$ & $6.97, \mathrm{~s}$ \\
\hline 3 & $77.7, \mathrm{C}$ & & $141.6, \mathrm{C}$ & \\
\hline 4 & $35.6, \mathrm{CH}_{2}$ & $\begin{array}{c}3.76, d(18.6) \\
3.00, d(18.6,1.6)\end{array}$ & $114.2, \mathrm{CH}$ & $7.55, \mathrm{~s}$ \\
\hline $4 a$ & $139.4, \mathrm{C}$ & & $128.2, \mathrm{C}$ & \\
\hline 5 & $163.4, \mathrm{C}$ & & $162.8, \mathrm{C}$ & \\
\hline $5 a$ & 119.1, C & & 108.6, C & \\
\hline 6 & $189.9, \mathrm{C}$ & & $186.3, \mathrm{C}$ & \\
\hline $6 a$ & $133.9, \mathrm{C}$ & & $132.7, \mathrm{C}$ & \\
\hline 7 & 121.2, CH & $7.90, d(8.0)$ & 118.7, CH & $7.79, \mathrm{~d}(7.9)$ \\
\hline 8 & 135.6, $\mathrm{CH}$ & $8.02, \mathrm{~d}(8.0)$ & $132.1, \mathrm{CH}$ & $7.85, \mathrm{~d}(7.9)$ \\
\hline 9 & $140.5, \mathrm{C}$ & & 137.3, C & \\
\hline 10 & $160.8, \mathrm{C}$ & & $158.4, \mathrm{C}$ & \\
\hline $10 a$ & $117.6, \mathrm{C}$ & & $116.6, \mathrm{C}$ & \\
\hline 11 & $189.8, \mathrm{C}$ & & 187.3, C & \\
\hline $11 a$ & $132.6, \mathrm{C}$ & & 125.0, C & \\
\hline 12 & $117.4, \mathrm{CH}$ & $8.34, \mathrm{~s}$ & $116.8, \mathrm{CH}$ & $8.45, \mathrm{~s}$ \\
\hline $12 \mathrm{a}$ & $140.2, \mathrm{C}$ & & $124.1, \mathrm{C}$ & \\
\hline 13 & $27.2, \mathrm{CH}_{3}$ & $1.56, \mathrm{~s}$ & $21.8, \mathrm{CH}_{3}$ & $2.43, \mathrm{~s}$ \\
\hline $1^{\prime}$ & $73.3, \mathrm{CH}$ & $5.07, \mathrm{~d}(9.5)$ & $70.5, \mathrm{CH}$ & $4.80, \mathrm{~d}(11.9)$ \\
\hline $2^{\prime}$ & $38.3, \mathrm{CH}_{2}$ & $2.40, \mathrm{~m} ; 1.63, \mathrm{~m}$ & $38.4, \mathrm{CH}_{2}$ & $2.40, \mathrm{~m} ; 1.36, \mathrm{~m}$ \\
\hline $3^{\prime}$ & $78.4, \mathrm{CH}$ & $3.91, \mathrm{~m}$ & $70.2, \mathrm{CH}$ & $3.68, \mathrm{~m}$ \\
\hline $4^{\prime}$ & $76.1, \mathrm{CH}$ & $3.60, \mathrm{~m}$ & $84.3, \mathrm{CH}$ & $3.12, \mathrm{t}(8.8)$ \\
\hline $5^{\prime}$ & $76.1, \mathrm{CH}$ & $3.64, q(6.2)$ & $74.9, \mathrm{CH}$ & $3.50, \mathrm{q}(6.5)$ \\
\hline $6^{\prime}$ & $18.4, \mathrm{CH}_{3}$ & $1.34, \mathrm{~d}(6.2)$ & $18.3, \mathrm{CH}_{3}$ & $1.30, \mathrm{~d}(6.5)$ \\
\hline $1^{\prime \prime}$ & $93.2, \mathrm{CH}$ & $5.26, d(3.0)$ & $97.3, \mathrm{CH}$ & 4.94, br s \\
\hline $2^{\prime \prime}$ & $73.1, \mathrm{CH}$ & $4.44, \mathrm{dd}(6.0,3.0)$ & $24.1, \mathrm{CH}_{2}$ & $1.99, \mathrm{~m} ; 1.56, \mathrm{~m}$ \\
\hline $3^{\prime \prime}$ & $41.6, \mathrm{CH}$ & $2.84, \mathrm{~m} ; 2.56, \mathrm{~m}$ & $24.3, \mathrm{CH}_{2}$ & $2.28, \mathrm{~m} ; 1.90, \mathrm{~m}$ \\
\hline $4^{\prime \prime}$ & $209.5, \mathrm{C}$ & & $75.0, \mathrm{CH}$ & $3.68, \mathrm{~m}$ \\
\hline $5^{\prime \prime}$ & $79.2, \mathrm{CH}$ & $4.79, \mathrm{q}(6.2)$ & $66.1, \mathrm{CH}$ & $4.33, q(6.5)$ \\
\hline $6^{\prime \prime}$ & $17.4, \mathrm{CH}_{3}$ & $1.28, \mathrm{~d}(6.2)$ & 16.7, $\mathrm{CH}_{3}$ & $1.10, \mathrm{~d}(6.5)$ \\
\hline $1^{\prime \prime \prime}$ & $91.9, \mathrm{CH}$ & 5.17, br s & $94.3, \mathrm{CH}$ & $5.35, \mathrm{~d}(3.1)$ \\
\hline $2^{\prime \prime \prime}$ & $26.6, \mathrm{CH}_{2}$ & $2.00, \mathrm{~m} ; 1.60, \mathrm{~m}$ & 144.7, CH & $7.08, \mathrm{dd}(10.2,3.1)$ \\
\hline $3^{\prime \prime \prime}$ & $25.8, \mathrm{CH}_{2}$ & $2.40, \mathrm{~m}$ & $126.1, \mathrm{CH}$ & $6.08, d(10.2)$ \\
\hline $4^{\prime \prime \prime}$ & 77.7, $\mathrm{CH}$ & $3.64, \mathrm{~m}$ & $196.6, \mathrm{C}$ & \\
\hline $5^{\prime \prime \prime}$ & $68.6, \mathrm{CH}$ & $3.18, \mathrm{q}(7.0)$ & $69.6, \mathrm{CH}$ & $4.55, \mathrm{q}(6.7)$ \\
\hline $6^{\prime \prime \prime}$ & $18.4, \mathrm{CH}_{3}$ & $0.64, \mathrm{~d}(7.0)$ & $14.9, \mathrm{CH}_{3}$ & $1.24, \mathrm{~d}(6.7)$ \\
\hline $1^{\prime \prime \prime \prime}$ & $96.9, \mathrm{CH}$ & $5.13, \mathrm{~d}(3.4)$ & & \\
\hline $2^{\prime \prime \prime \prime}$ & 146.0, $\mathrm{CH}$ & 6.93, dd $(10.0,3.4)$ & & \\
\hline $3^{\prime \prime \prime \prime}$ & $128.1, \mathrm{CH}$ & $5.97, \mathrm{~d}(10.0)$ & & \\
\hline $4^{\prime \prime \prime \prime}$ & 198.2, C & & & \\
\hline $5^{\prime \prime \prime \prime}$ & $71.9, \mathrm{CH}$ & 4.49, q (6.2) & & \\
\hline $6^{\prime \prime \prime \prime}$ & $16.4, \mathrm{CH}_{3}$ & $1.21, \mathrm{~d}(6.2)$ & & \\
\hline
\end{tabular}

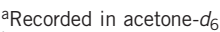

becorded in DMSO- $d_{6} / \mathrm{CDCl}_{3}(5: 1)$.

inhibition to Jurkat T-cell proliferation with $\mathrm{IC}_{50}$ values of 11 and $37 \mathrm{~nm}$, respectively, which were more or nearly equally efficient than that of the positive control, doxorubicin. Vineomycin $\mathrm{B}_{2}(5)$ displayed powerful inhibitory effect to Jurkat $\mathrm{T}$ cells with an $\mathrm{IC}_{50}$ value of $0.3 \mu \mathrm{m}$. The new compound 2 showed cytotoxicity against Jurkat $\mathrm{T}$ cells with an $\mathrm{IC}_{50}$ value of $3.0 \mu \mathrm{M}$, while new compound 1 showed no cytotoxic activity at the concentration of $20 \mu \mathrm{M}$ (Table 2).

\section{DISCUSSION}

Following the evidence of heterologous expression of GCN gene cluster, five angucycline glycosides containing L-aculose at the end of sugar chains, which was different from the terminal sugar unit L-cinerulose A in our previously reported GCNs, were identified from marinederived actinomycete S. lusitanus SCSIO LR32. ${ }^{4}$ The core skeleton of the new compounds $\mathbf{1}$ and $\mathbf{2}$ is the rearranged galtamycin-type non-classic aglycone of angucycline. ${ }^{1}$ However, compounds $\mathbf{1}$ and $\mathbf{2}$ showed lower cytotoxicity on Jurkat $\mathrm{T}$ cells than the known compounds $\mathbf{3}$ and $\mathbf{4}$, which possess a classic aquayamycin-type aglycone. ${ }^{1}$ Compound $\mathbf{5}$ has a tricyclic non-classic aglycone, ${ }^{1}$ which exhibited moderate cytotoxicity among the five compounds. These results indicated that the chemical and biological diversity of angucyclines derived not only from the sugar unit but also from the aglycone moiety.

\section{MATERIALS AND METHODS}

\section{General experimental procedures}

Column chromatography (CC) was performed by using silica gel (100-200 mesh; Jiangpeng Silica Gel Development, Inc., Yantai, China) or Sephadex LH-20 (40-70 $\mu \mathrm{m}$; GE Healthcare, Uppsala, Sweden). TLC was conducted with precoated glass plates $\left(0.1-0.2 \mathrm{~mm}\right.$; silica gel $\mathrm{GF}_{254}, 10-40 \mathrm{~nm}$, Jiangpeng). HPLC analyses were performed with a 1260 infinity system (Agilent, Santa Clara, CA, USA) using a Phenomenex Prodigy ODS (2) column $(150 \times 4.6 \mathrm{~mm}, 5 \mu \mathrm{m}$; Torrance, CA, USA). Semipreparative HPLC was performed with a Primaide 1110 solvent delivery module equipped with a 1430 photodiode array detector (Hitachi, Japan), using a YMC-Pack ODS-A column $(250 \times 10 \mathrm{~mm}, 5 \mu \mathrm{m}$; Kyoto, Japan). UV spectra were recorded on a U-2910 spectrometer (Shimadzu, Tokyo, Japan); IR spectra were obtained on an IRAffinity-1 spectrophotometer (Shimadzu). High-resolution mass spectral data were obtained on a MaXis Q-TOF mass spectrometer (Bruker, Rleigh, NC, USA). Optical rotations were recorded with an MCP-500 polarimeter (Anton Paar, Graz, Austria). NMR spectra were recorded on an Avance 500 spectrometer (Bruker) at $500 \mathrm{MHz}$ for ${ }^{1} \mathrm{H}$ nuclei and $125 \mathrm{MHz}$ for ${ }^{13} \mathrm{C}$ nuclei. Chemical shifts $(\delta)$ were given with reference to tetramethyl silane (TMS) or solvent residue signal. Coupling constants $(J)$ were given in $\mathrm{Hz}$.

\section{Fermentation}

The isolation and characterization of strain SCSIO LR32 have been described previously. ${ }^{4}$ A portion of SCSIO LR32 spore suspension containing about $2.16 \times 10^{7}$ spores was inoculated into $100 \mathrm{ml}$ modified $\mathrm{AM}_{2}$ medium $(0.5 \%$ soluble starch, $0.5 \%$ yeast extract, $0.2 \%$ peptone, $2.0 \%$ glucose, $0.05 \% \mathrm{KH}_{2} \mathrm{PO}_{4}, 0.05 \% \mathrm{MgSO}_{4} \cdot 7 \mathrm{H}_{2} \mathrm{O}, 0.4 \% \mathrm{NaCl}, 0.2 \% \mathrm{CaCO}_{3}, 3.0 \%$ sea salt, pH 7.2 before sterilization) in a $250 \mathrm{ml}$ Erlenmeyer flask and incubated at $30{ }^{\circ} \mathrm{C}$ for $48 \mathrm{~h}$ on a rotary shaker at 200 r.p.m. Then $600 \mathrm{ml}$ of the seed culture from six flasks was transferred into 81 modified $\mathrm{AM}_{2}$ medium in a 151 fermentor, with the agitation speed of 200 r.p.m. and the aeration rate of $51 \mathrm{~min}^{-1}$. After $24 \mathrm{~h}$ cultivation, the entire 81 seed culture was further transferred into a 1501 fermentor containing 801 production medium (0.5\% corn flour, $2 \%$ soluble starch, $0.5 \%$ yeast extract, $1 \%$ malt extract, $1 \%$ glucose, $1 \%$ maltose, $0.2 \% \mathrm{CaCO}_{3}, 3.0 \%$ sea salt, $\mathrm{pH} 7.2$ before sterilization) and cultivated at $30^{\circ} \mathrm{C}$. The dissolved oxygen of broth was maintained above $50 \%$ by adjusting the agitation speed and aeration rate. Broth sample was withdrawn every $24 \mathrm{~h}$ and centrifuged; the resulting supernatant was applied for the residual sugar measurement, and the mycelium pellets were extracted with methanol for further HPLC analysis. The fermentation was terminated after 7 days of cultivation. The entire 801 broth was harvested and centrifuged to yield a mycelial cake and a liquid broth.

\section{Extraction and isolation}

Each $500 \mathrm{~g}$ mycelial cake was extracted with 11 acetone three times. The acetone layers were combined and vacuum dried to yield a residue. The residue was subjected to a $\mathrm{SiO}_{2} \mathrm{CC}$ using gradient elution with $\mathrm{CHCl}_{3}$ and $\mathrm{MeOH}$ mixtures $(100: 0,99: 1,97: 3,95: 5,90: 10,80: 20$ and 50:50, v/v) to give seven fractions (Fr.A1 Fr.A7). Fr.A1 and Fr.A2 were combined after HPLC analysis and 


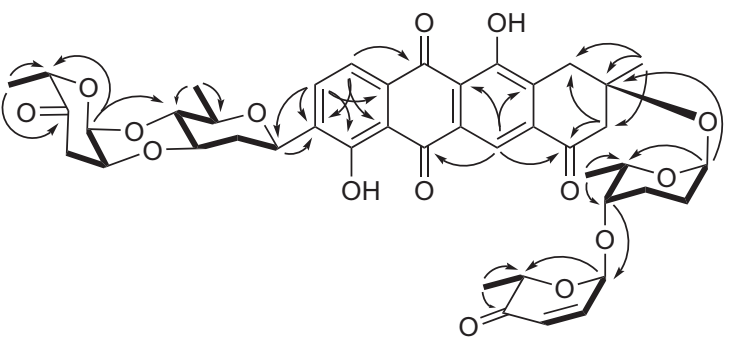

1

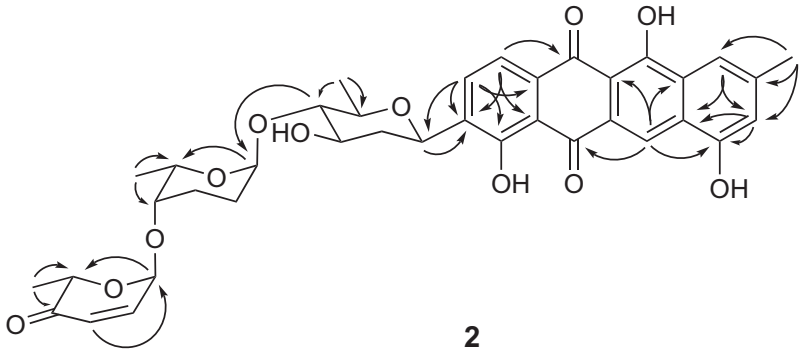

Figure 2 Key HMBC (arrows) and COSY (bold lines) correlations of grincamycins $\mathrm{G}(1)$ and $\mathrm{H}(2)$.

Table 2 Cytotoxicities $\left(\mathrm{IC}_{50}\right.$ values, $\left.\mu \mathrm{m}\right)$ of compounds $1-5$ against Jurkat $T$ cells

\begin{tabular}{ccccccc}
\hline & $\mathbf{1}$ & $\mathbf{2}$ & $\mathbf{3}$ & $\mathbf{4}$ & $\mathbf{5}$ & Doxorubicin $^{\mathrm{a}}$ \\
\hline $\mathrm{IC}_{50}$ & $>20.0$ & 3.0 & 0.011 & 0.037 & 0.3 & 0.034 \\
\hline
\end{tabular}

aPositive control.

purified by $\mathrm{SiO}_{2}$ CC eluting with petroleum ether and EtOAc mixtures (100:0, $90: 10, \quad 80: 20, \quad 70: 30,60: 40, \quad 40: 60, \quad 20: 80, \quad 0: 100, \quad v / v)$ to give eight fractions $(\mathrm{Fr} . \mathrm{B} 1 \sim \mathrm{Fr} . \mathrm{B} 8)$. Fr.B3 was purified by semipreparative HPLC with an ODS column eluted with $\mathrm{CH}_{3} \mathrm{CN} / \mathrm{H}_{2} \mathrm{O}$ (30:70 to 100:0 over 28 min and then held for $\left.7 \mathrm{~min} 2.5 \mathrm{ml} \mathrm{min}^{-1}\right)$ to afford $2(8 \mathrm{mg})$ at $t_{\mathrm{R}} 32 \mathrm{~min}$. Fr.B4 was subjected to Sephadex LH-20 CC eluted with $\mathrm{CHCl}_{3} / \mathrm{MeOH}$ (1:1) to obtain $1(6 \mathrm{mg})$ and $4(12 \mathrm{mg})$. Fr.B5 and Fr.B6 were combined and further purified by semipreparative HPLC with an ODS column using the same elution procedure to afford $3(220 \mathrm{mg})$ at $t_{\mathrm{R}} 26 \mathrm{~min}$ and $\mathbf{5}(7 \mathrm{mg})$ at $t_{\mathrm{R}} 30 \mathrm{~min}$.

Grincamycin $G$ (1): Yellowish powder; $[\alpha]^{20}{ }_{D}=+53$ (c 0.09 , acetone); $\mathrm{UV}(\mathrm{MeOH}) \lambda_{\max }(\log \varepsilon) 214$ (4.32), 243 (4.26), 265 (4.30), 443 (3.86); ${ }^{1} \mathrm{H}$ NMR $\left(500 \mathrm{MHz}\right.$, acetone- $\left.d_{6}\right)$ and ${ }^{13} \mathrm{C}$ NMR $\left(125 \mathrm{MHz}\right.$, acetone- $\left.d_{6}\right)$ data are listed in Table 1; (-)HR-ESI-MS $\mathrm{m} / \mathrm{z} 801.2776\left([\mathrm{M}-\mathrm{H}]^{-}\right.$, calcd for $\left.\mathrm{C}_{43} \mathrm{H}_{45} \mathrm{O}_{15}, 801.2764\right)$.

Grincamycin $G$ (2): Dark-red powder; $[\alpha]^{20}{ }_{D}=+65$ (c 0.10 , acetone); $\mathrm{UV}(\mathrm{MeOH}) \lambda_{\max }(\log \varepsilon) 230$ (4.39), 258 (4.15), 294 (3.68), 492 (3.79); ${ }^{1} \mathrm{H}$ NMR $\left(500 \mathrm{MHz}\right.$, DMSO- $\left.d_{6} / \mathrm{CDCl}_{3}\right)$ and ${ }^{13} \mathrm{C}$ NMR $(125 \mathrm{MHz}$, DMSO- $d_{6} / \mathrm{CDCl}_{3}$ ) data are listed in Table 1; (-)HR-ESI-MS $\mathrm{m} / z 673.2311$ ([M-H] $]^{-}$, calcd for $\mathrm{C}_{37} \mathrm{H}_{37} \mathrm{O}_{12}, 673.2291$ ).

\section{Cytotoxic activity assay}

Proliferation-inhibition assay against Jurkat $\mathrm{T}$ cells was conducted according to the previously reported method. ${ }^{15}$ Jurkat T cells $\left(2 \times 10^{4}\right.$ cells per well) were maintained in RPMI 1640 medium with $10 \%$ fetal bovine serum at $37^{\circ} \mathrm{C}$, in $5 \% \mathrm{CO}_{2}$. For cytotoxic activity assay, Jurkat $\mathrm{T}$ cells were seeded in a 96-well plate and treated with compounds as indicated and then incubated at $37^{\circ} \mathrm{C}$ for $72 \mathrm{~h}$. The viability of cells were measured by adding alamarblue dye $(1: 10)$ to each well, and the plate was incubated at $37^{\circ} \mathrm{C}$ for $4 \mathrm{~h}$ before fluorescence intensity was obtained by Flexstation3 (Molecular Devices, Sunnyvale, CA, USA). All data were processed with Prism6 (La Jolla, CA, USA).

\section{CONFLICT OF INTEREST}

The authors declare no conflict of interest.

\section{ACKNOWLEDGEMENTS}

This study was supported in part by the National Science Foundation of China (41476133) and the projects of Guangdong Provincial Oceanic and Fishery Administration (A201401C05). We express our thanks to the analytical facility center (Ms Sun, Ms Zhang, Mr Li and Ms Xiao) of the South China Sea Institute of Oceanology for measuring MS and NMR data.

1 Rohr, J. \& Thiericke, R. Angucycline group antibiotics. Nat. Prod. Rep. 9, 103-137 (1992).

2 Kharel, M. K. et al. Angucyclines: biosynthesis, mode-of-action, new natural products, and synthesis. Nat. Prod. Rep. 29, 264-325 (2012).

3 Krohn, K. \& Rohr, J. Angucyclines: total syntheses, new structures, and biosynthetic studies of an emerging new class of antibiotics. Top. Curr. Chem. 188, 127-195 (1997).

4 Huang, H. et al. Cytotoxic angucycline class glycosides from the deep sea actinomycete Streptomyces lusitanus SCSIO LR32. J. Nat. Prod. 75, 202-208 (2012)

5 Zhang, Y. et al. Identification of the grincamycin gene cluster unveils divergent roles for GcnQ in different hosts, tailoring the L-rhodinose moiety. Org. Lett. 15, 3254-3257 (2013)

6 Henkel, T. \& Zeeck, A. Derivatives of saquayamycins A and B. Regio- and diastereoselective addition of alcohols to the L-aculose moiety. J. Antibiot. 43, 830-837 (1990).

7 Qian-Cutrone, F. et al. Quanolirones I and II, two new human cytomegalovirus protease inhibitors produced by Streptomyces sp. WC76535. J. Nat. Prod. 61, 1379-1382 (1998)

8 Alvi, K. A. et al. Identification of inhibitors of inducible nitric oxide synthase from microbial extracts. J. Antibiot. 53, 496-501 (2000).

9 Ströch, K. et al. Retymicin, galtamycin B, saquayamycin Z and ribofuranosyllumichrome, novel secondary metabolites from Micromonospora sp. Tü 6368. II. Structure elucidation. J. Antibiot. 58, 103-110 (2005).

10 Kusumi, S. et al. Total synthesis of vineomycin B2. J. Am. Chem. Soc. 135, 15909-15912 (2013).

11 Ohta, K. et al. The absolute configuration of P-1894B, a potent prolyl hydroxylase inhibitor. Chem. Pharm. Bull. 32, 4350-4359 (1984).

12 Okazaki, H. et al. A potent prolyl hydroxylase inhibitor, P-1894B, produced by a strain of Streptomyces. J. Antibiot. 34, 1355-1356 (1981).

13 Uchida, T. et al. Saquayamycins, new aquayamycin-group antibiotics. J. Antibiot. 38, 1171-1181 (1985).

14 Imamura, N. et al. The structure of vineomycin B2. J. Antibiot. 34, 1517-1518 (1981).

15 Zhong, W.-M. et al. Three minor new compounds from the aerial parts of Leonurus japonicas. Chin. Chem. Lett. 26, 1000-1003 (2015).

Supplementary Information accompanies the paper on The Journal of Antibiotics website (http://www.nature.com/ja) 